\title{
POLA INTERAKSI ANTARA GURU DENGAN SISWA PADA MATA PELAJARAN PAI DI SMP N 2 RANDUDONGKAL
}

\author{
M. Mualif \\ Prodi Teknik Industri Universitas Pamulang \\ dosen01255@unpam.ac.id
}

Naskah diterima: 25 Januari 2021, direvisi: 30 April 2021, disetujui: 10 Juli 2021

\section{Abstrak}

Guru dan siswa merupakan dua komponen pendidikan yang tidak terpisahkan. Guru adalah orang yang memberi ilmu pengetahuan kepada siswa. Siswa sendiri merupakan sebuah subjek belajar yang akan selalu menghantarkan kehadiran seorang guru untuk membimbingnya. Interaksi antara guru dengan siswa dalam konteks pendidikan adalah suatu proses menunjukkan pada hubungan-hubungan yang dinamis. Interaksi di sini merupakan syarat utama adanya aktivitas dari hubungan dinamis yang bermuara kepada siswa sebagai objek satuan pendidikan. Hubungan yang dilakukan antara individu kadang-kadang hanya berlangsung singkat, tetapi dapat berlangsung lama. Hubungan yang berlangsung lama biasanya ditandai oleh derajat keeratan yang semakin kuat.

Jenis penelitian ini adalah studi lapangan (field research). Sedangkan pendekatan yang digunakan adalah pendekatan kualitatif. Sedangkan metode pengumpulan data dalam penelitian ini observasi, interview, dan dokumentasi. Adapun dalam menganalisis data peneliti menggunakan analisis deskriptif.

Hasil penelitian menunjukkan bahwa: pertama, pola interaksi antara guru dengan siswa ada tiga pola, yaitu pola interaksi demokratis, pola interaksi liberalis, dan pola interaksi feodalis. Adapun dalam pelaksanaannya pola interaksi antara guru dengan siswa pada mata pelajaran PAI di SMP N 2 Randudongkal menerapkan pola interaksi demokratis. Kedua, faktor-faktor yang mempengaruhi pola interaksi antara guru dengan siswa pada mata pelajaran PAl di SMP N 2 Randudongkal, antara lain: keadaan guru, keadaan siswa,keadaan lingkungan, sarana dan prasarana, dan kurikulum.

Kata Kunci : Pola Interaksi, Guru, Siswa. 


\section{PENDAHULUAN}

Manusia adalah makhluk sosial yang selalu akan berinteraksi dengan manusia lainnya dalam berbagai hal. Dipengaruhi oleh kebutuhan hidup manusia yang sanga tkompleks dan tidak dapat dipenuhi sendiri. Semua terjadi sejak manusia dilahirkan dimuka bumi ini hingga manusia itu kembali keSang pencipta. Interaksi antar manusia terjadi dalam berbagai lini kehidupan manusia itu sendiri dalam rangka memenuhi kebutuhannya. Diantara kebutuhan manusia yang dibutuhkan oleh seorang individu akan terpenuhi dengan cara berinteraksi dengan sumber pengetahuan yang dimaksud. Pendidikan sebuah jalur formal dalam menuntut ilmu akan membawa sebuah konsep interaksi antar pendidik dan peserta didik. Sosok seorang pendidik merupakan figure manusia sumber yang menempati posisi dan peranan penting dalam Pendidikan (Djamarah, 2000: 1).

Sekolah merupakan salah satu sarana yang diperlukan untuk mendapatkan pendidikan. Dalam konteks sekarang sekolah merupakan agen berlakunya perubahan sosial (Shaleh Lebar: 47). Di sekolah pendidik mempunyai peranan yang sangat penting. Sebagai pendidik, guru mempunyai tanggung jawab dan tugas untuk menyampaikan ilmu pengetahuan dan membantu perkembangan seorang peserta didik. Disinilah seorang pendidik akan berinteraksi dengan peserta didik.

Disekolah anak berinteraksi dengan pendidik-pendidik (pengajar) yang berdisiplin beserta bahan-bahan pengajar, teman-teman peserta didik yang rajin, beserta pegawai-pegawai yang giat bekerja. Akibat bersosialisasi dengan mereka terbentuklah kepribadian peserta didik yang baik. Sebaliknya akibat berinteraksi dengan para pendidik (pengajar) yang kurang disiplin, teman-teman sekolahnya yang kurang tertib, membolos, malas belajar dan sebagainya, maka terpengaruhlah kepribadian peserta didik menjadi kurang baik. Akibatnya setelah lulus prestasi akademiknya merosot, dan mempunyai kepribadian yang tidak bisa menempatkan dalam pergaulan dilingkungan sekolah berikutnya, keluarga, maupun masyarakat (Gunawan, 2002: 10).

$$
\text { Interaksi adalah kontak }
$$

langsung antara satu individu dengan individu lain atau antara pendidik dan peserta didik. Interasi merupakan salah satu sarana untuk mencapai pendidikan yang baik. Interaksi atau kontak langsung antara satu individu dengan individu lain atau antara pendidik dengan peserta didik ini memungkinkan timbulnya cinta pada peserta didik dari pendidik atau sebaliknya. Dalam interaksi itu pendidik dapat mengobservasikan secara langsung, untuk menemukan potensi-potensi yang ada pada peserta didik, sedangkan peserta didik lewat interaksi itu dapat mengetahui secara langsung apa yang ada pada pendidik, kecintaannya, rasa sosialnya, keprigelannya dedikasihnya. (Uhbiyati, 1991: 1).

Interaksi antara guru dan siswa dalam konteks pendidikan adalah suatu proses menunjukkan pada hubunganhubungan yang dinamis. Interaksi di sini merupakan syarat utama adanya aktifitas dari interaksi dinamis yang bermuara kepada siswa sebagai satuan obyek satuan pendidikan. Interaksi yang dilakukan antara individu kadang- 
kadang hanya berlangsung singkat, tetapi dapat juga berlangsung lama. Interaksi yang berlangsung lama biasanya ditandai oleh derajat keeratan yang semakin kuat.

Jadi hubungan guru dengan siswa atau anak didik di dalam proses belajar mengajar merupakan faktor yang sangat menentukan dalam keberhasilan siswa. Bagaimanapun baiknya materi pelajaran, metode pembelajaran yang digunakan dalam pembelajaran, jika pola interaksi guru dengan siswa kurang baik, komunikasi jarang dilakukan maka hasilnya pun tidak maksimal yang menyebabkan tujuan pembelajaran tidak dapat tercapai. Proses interaksi akan selalu ada di setiap lembaga pendidikan. Demikian pula yang ada di SMP $\mathrm{N} 2$ RandudongkalKabupaten Pemalang, adapun dalam setiap komunitas lembaga pendidikan akan mempunyai ciri khas tersendiri.

Berangkat dari pemaparan latar belakang di atas penulis tertarik untuk meneliti lebih lanjut dengan mengangkat tema yang berjudul " Pola Interaksi Antara Guru dengan Siswa pada Mata Pelajaran PAl di SMP N 2 Randudongkal", adapun alasan penulis memilih judul tersebut adalah :

I. Tugas dan peran seorang guru dalam mewarnai sebuah proses kegiatan belajar mengajar yang signifikan

2. Pola interaksi guru dan murid dalam menunjang keberhasilan belajar.

\section{METODE PENELITIAN}

Penelitian ini merupakan penelitian lapangan (field research) dengan menggunakan pendekatan kualitatif. Teknik pengumpulan datanya adalah dengan menggunakan metode observasi untuk Metode observasi digunakan untuk kegiatan pembelajaran yang memperlihatkan pola interaksi antara guru dengan siswa pada mata pelajaran PAl di SMP N 2 Randudongkal. Metode wawancara untuk untuk menggali data terkait dengan pola interaksi antara guru dengan siswa pada mata pelajaran PAl dan faktor-faktor yang mempengaruhi pola interaksi pada mata pelajaran PAl di SMP $\quad \mathrm{N} 2$ Randudongkal. Untuk teknik analisis data yang menggunakan analisis deskriptif.

\section{PEMBAHASAN DAN HASIL PENELITIAN}

Pola Interaksi antara Guru dengan Siswa Pada Mata Pelajaran PAl

Guru dan murid adalah dua buah elemen pendidikan yang tidak dapat dipisahkan satu sama lain. Keberadaan seorang guru tidaklah memiliki arti manakala tidak ada sosok seorang murid untuknya. Bahkan dengan demikian seseorang tidak dapat dikatakan sebagai guru jika tidak memiliki murid baik secara langsung maupun tak langsung menimba ilmu darinya. Guru dan murid juga merupakan seorang makhluk mulia manakala kedua sosok tersebut merupakan benar-benar mengabdikan kehidupannya demi ilmu pengetahuan. Karena dengan ilmu pengetahuan pulalah manusia dapat menjaga eksistensinya dimuka bumi ini.

Dalam sebuah institusi pendidikan, guru adalah orang tua kedua bagi muridnya. Sebagai orang tua, guru harus benar-benar mencurahkan segala pengetahuan yang ada pada dirinya dengan penuh kasih sayang sebagaimana kasih sayang orang 
tua kepada anaknya. Karena dengan demikian diharapkan hubungan antara guru dan murid dapat memotivasi kedua belah pihak dalam mengeksploitasi ilmu pengetahuan. Sehingga keberhasilan dalam kegiatan belajar mengajar dapat dicapai dengan optimal. Karena pada hakikatnya antara guru dengan murid memiliki kesamaan langkah dan tujuan.

Pola Interaksi antara guru dengan siswa dapat digolongkan menjadi tiga pola, yaitu pola interaksi demokratis, pola interaksi liberalis, dan pola interaksi feodalis.

1. Pola interaksi demokratis

Pola interaksi demokratis ditunjukkan dengan adanya interaksi antara guru dengan siswa yang sangat akrab dan terjalin interaksi yang komunikatif. Pembelajaran yang digunakan bersifat bebas dan terbuka sesuai dengan tujuan yang akan dicapai. Proses pembelajaran dapat dilakukan diruangan ataupun di luar ruangan dengan memanfaatkan fasilitas ataupun alatalat bantu yang dapat, endukung dan menunjang kegiatan belajar mengajar demi tercapainya keberhasilan yang optimal.

Sikap demokratisasi dalam pendidikan perlu dikembangkan supaya siswa dapat mengeksplorasi pikirannya dalam mengemukakan pendapat, dan pendidik dapat melihat bakat masing-masing anak dari proses siswa ketika berinteraksi, berkomunikasi maupun menyalurkan hal-hal yang disukainya. Suasana demokratis dalam pendidikan akan menghasilkan anak-anak yang kritis, progresif dan aktif.
Dengan demikian demokratisasi pendidikan dapat berpengaruh positif terhadap keberhasilan belajar siswa. Artinya semakin efektif upaya demokratisasi pendidikan maka semakin baik pula keberhasilan belajar siswa. Hal ini dapat dilihat dari nilai raport yang cukup bagus dan juga mencerminkan dalam perubahan tingkah laku siswa seperti siswa aktif dalam proses pembelajaran dengan didukung suasana belajar yang menyenangkan dan membangkitkan motivasi maupun minat belajar siswa. Selain itu dapat mencerminkan perubahan tingkah laku yang menunjukkan akhlakul karimah serta perubahan yang berorientasi ke masa depan.

2. Pola interaksi liberalis

Pola interaksi liberalis ditunjukkan dengan adanya guru yang membebaskan siswa tanpa batasan, munculnya suasana yang tidak kondusif dalam belajar mengajar itu dikarenakan dimana seorang siswa tidak menghormati guru, siswa tidak sopan, siswa menganggap guru teman bercanda, siswa menggunjingkan guru-gurunya, dan sebaliknya guru acuh dan tidak peduli terhadap apa yang terjadi pada siswa.

3. Pola interaksi feodalis

Pola interaksi feodalis ditunjukkan dengan adanya salah satu guru yang tidak memberi kesempatan siswa untuk aktif dalam KBM. Ketika salah seorang siswa menyampaikan pendapatnya, guru tidak mempersilahkan, akan tetapi justru memarahi siswa tersebut. Hal ini membuat siswa pasif, yang hanya terbatas pada menerima, mencatat, 
dan menyimpan informasi pelajaran saja. Yang akhirnya menjadikan kemalasan bagi siswa untuk mengekspresikan pendapatnya.

Namun berdasarkan hasil observasi dan interview yang peneliti lakukan ternyata guru PAl di SMP Negeri 2 Randudongkal menggunakan satu pola interaksi:

\section{Pola Interaksi Demokratis}

Berdasarkan hasil wawancara dan observasi yang peneliti lakukan, menunjukan bahwa pola interaksi antara guru dengan siswa pada mata pelajaran PAl di SMP Negeri 2 Randudongkal adalah pola interaksi demokratis. Hasil analisis ini didukung oleh pernyataan dari Bapak Mulyadi, lbu Fadilah, Ibu Umi Latifah, Agung Indarto, Alvi Safitri, Jaelani, Mukti Amanah, Toni Saputra, Karina Apriliana, Eza Ziya Ghozi, Tia Rostyana. Dimana pola interaksi demokratis ditunjukkan dengan adanya interaksi antara guru dengan siswa yang sangat akrab dan terjalin interaksi yang komunikatif.

Sikap demokratisasi dalam pendidikan perlu dikembangkan supaya siswa dapat mengeksplorasi pikirannya dalam mengemukakan pendapat, dan guru dapat melihat bakat masingmasing anak dari proses siswa ketika berinteraksi, berkomunikasi, maupun menyalurkan hal-hal yang disukainnya. Suasana demokratis dalam pendidikan akan menghasilkan anak-anak yang kritis, progresif dan aktif. Dengan demikian demokratisasi pendidikan dapat berpengaruh positif guru dan murid adalah dua buah elemen pendidikan yang tidak dapat dipisahkan satu sama lain. Keberadaan seorang guru tidaklah memiliki arti manakala tidak ada sosok seorang murid untuknya. Bahkan dengan demikian seseorang tidak dapat dikatakan sebagai guru jika tidak memiliki murid baik secara langsung maupun tak langsung menimba ilmu darinya. Guru dan murid juga merupakan seorang makhluk mulia manakala kedua sosok tersebut merupakan benar-benar mengabdikan kehidupannya demi ilmu pengetahuan. Karena dengan ilmu pengetahuan pulalah manusia dapat menjaga eksistensinya dimuka bumi ini.

Faktor-Faktor yang mempengaruhi Pola Interaksi antara Guru dengan Siswa pada Mata Pelajaran PAl

Berdasarkan hasil wawancara dan observasi pada bab sebelumnya diketahui bahwa terdapat faktor-faktor yang mempengaruhi pola interaksi antara guru dengan siswa pada mata pelajaran PAl di SMP Negeri 2 Randudongkal.

Adapun faktor-faktor yang mempengaruhi pola interaksi antara guru dengan siswa pada mata pelajaran PAl di SMP Negeri 2 Randudongkal, antara lain:

\section{Keadaan guru}

Guru merupakan salah satu hal yang menunjang keberhasilan interaksi antara guru dengan siswa dalam pembelajaran PAl di SMP Negeri 2 Randudongkal. Profesionalitas guru ini terwujud dalam persiapan karena tanpa adanya persiapan yang baik maka tujuan pembelajaran tidak akan tercapai dengan maksimal. Selain itu, kreatifitas guru juga sangat mendukung terbentuknya interaksi yang edukatif antara guru dengan siswa dalam pembelajaran PAI.

\section{Keadaan siswa}

Siswa juga merupakan salah satu hal yang menunjang keberhasilan interaksi 
antara guru dengan siswa dalam peoses pembelajaran PAl di SMP Negeri 2 Randudongkal, karena kegiatan pembelajaran tidak akan terjadi bila hanya ada guru tanpa siswa atau sebaliknya. Dalam hal ini, keaktifan siswa dalam proses pembelajaran PAI menentukan keberhasilan dengan di dukung adanya interaksi antara guru dengan siswa. Selain keaktifan siswa dalam proses pembelajaran siswa juga diharuskan mampu mengutarakan pendapatnya di dalam pembelajaran PAl.

\section{Keadaan lingkungan}

Lingkungan juga berpengaruh dalam keberhasilan belajar siswa. Begitu juga dalam pembelajaran PAl di SMP Negeri 2 Randudongkal, lingkungan yang bersih, saling mengahargai satu sama lain dan menjalin hubungan yang harmonis baik siswa denga siswa, siswa denga guru, meupun staf TU itu sangat mempengaruhi interaksi yang terjadi di SMP Negeri 2 Randudongkal khususnya pada mata pelajaran PAI.

\section{Sarana dan prasarana}

Sarana dan prasarana juga salah satu hal yang menunjang proses belajar mengajar, begitupula sarana dan prasarana yang ada di SMP Negeri 2 Randudongkal dalam pembelajaran PAI dengan adanya mushola, alat-alat yang membantu untuk praktek dalam pembelajaran $\mathrm{PAl}$ sangat mempengaruhi interaksi antara guru dengan siswa dan terlaksanannya proses belajar mengajar.

\section{Kurikulum}

Kurikulum yang berganti-ganti sangat mempengaruhi proses pembelajaran begitu juga yang ada di SMP Negeri 2 Randudongkal yang berganti kurikulum KTSP menjadi Kurikulum 2013 itu sangat mempengaruhi proses pembelajaran salah satunya dalam pembelajaran PAI di SMP Negeri 2 Randudongkal. Begitu pula interaksi yang terjadi antara guru dengan siswa adanya sering bergantinya kurikulum yang menjadikan siswa lebih aktif dalam proses pembelajaran dan guru lebih membebaskan siswa untuk bertanya dan mengutarakan pendapatnya.

\section{KESIMPULAN}

Berdasarkan analisis dan
pengkajian terhadap Pola Interaksi
Antara Guru Dengan Siswa Pada Mata
Pelajaran PAl di SMP N 2
Randudongkal, dapat peneliti simpulkan
sebagai berikut:

1. Pola interaksi antara guru dengan siswa pada mata pelajaran PAl di SMP N 2 Randudongkal menggunakan pola interaksi demokratis. Dimana pola ini menunjukan adanya suatu interaksi yang baik, bebas, dan terbuka yang terjalin antara guru dengan siswa. Bebas disini dalam artian, bahwa interaksi yang tercipta antara keduannya itu ada batas dan aturannya dalam berinteraksi. Sehingga tidak keluar dari batasanbatasan tersebut dan sesuai dengan aturan yang telah ditetapkan. Dengan adanya interaksi demokratis ini, akan mempermudah seorang guru dalam mengidentifikasi masalah yang yang dihadapi siswa, baik masalah pribadi maupun masalah kesulitan dalam belajar yang dapat menghambat proses belajarnya di dalam kelas. Sehingga pola interaksi demokratis ini penting untuk di wujudkan.

2. Faktor-faktor yang mempengaruhi pola interaksi antara guru dengan 
siswa pada mata pelajaran $\mathrm{PAl}$ di SMP N 2 Randudongkal yaitu:

a. Keadaan guru

Profesionalitas guru ini terwujud dalam persiapan karena tanpa adanya persiapan yang baik maka tujuan pembelajaran tidak akan tercapai dengan maksimal. Selain itu, kreatifitas guru juga sangat mendukung terbentuknya interaksi yang edukatif antara guru dengan siswa dalam pembelajaran PAl.

b. Keadaan siswa

Kegiatan pembelajaran tidak akan terjadi bila hanya ada guru tanpa siswa atau sebaliknya. Dalam hal ini, keaktifan siswa dalam proses pembelajaran $\mathrm{PAI}$ menentukan keberhasilan dengan di dukung adanya interaksi antara guru dengan siswa. Selain keaktifan siswa dalam proses pembelajaran siswa juga diharuskan mampu mengutarakan pendapatnya di dalam pembelajaran $\mathrm{PAI}$.

c. Keadaan lingkungan

lingkungan yang bersih, saling mengahargai satu sama lain dan menjalin hubungan yang harmonis baik siswa denga siswa, siswa denga guru, meupun staf TU itu sangat mempengaruhi interaksi yang terjadi di SMP Negeri 2 Randudongkal khususnya pada mata pelajaran PAl.

d. Sarana dan prasarana

Adanya mushola, alat-alat yang membantu untuk praktek dalam pembelajaran $\mathrm{PAl}$ sangat mempengaruhi interaksi antara guru dengan siswa dan terlaksanannya proses belajar mengajar.

e. Kurikulum

Begitu pula interaksi yang terjadi antara guru dengan siswa adanya sering bergantinya kurikulum yang menjadikan siswa lebih aktif dalam proses pembelajaran dan guru lebih membebaskan siswa untuk bertanya dan mengutarakan pendapatnya.

\section{DAFTAR PUSTAKA}

Ahmadi, Abu dan Nur Uhbiyati. (2008). llmu Pendidikan. Jakarta: PT. Rineka Cipta

Alim, Mohammad, dkk. (2005). Psikologi Remaja perkembangan Peserta Didik. Jakarta: PT. Bumi aksara

Arifin, H.M. (1996). Ilmu Pendidikan Islam (Suatu Tinjauan Teoritis dan Praktis Berdasarkan Pendekatan Interdisipliner). Jakarta: Bumi Aksara

Arikunto, Suharsini. (2002). Manajemen Penelitian. Jakarta: Rineka Cipta

Arikunto, Suharsini. (2006). Prosedur Penelitian Suatu Pendekatan Praktik. Jakarta: PT. Rineka Cipta

Bahreisy, Salim. 1976. Tarjamah Riadhus Shalihin Jilid 1. Bandung: PT. AlMa'arif

Burhanudin. (2004). Pengantar Pedagogik Dasar-dasar Ilmu Mendidik. Cet. 6 Jakarta: Rineka Cipta

Departemen Agama Rl. (2004). Pedoman Pendidikan Agama Islam. Jakarta: Direktorat 
Jenderal Kelembagaan Agama Islam

Departemen Pendidikan dan Kebudayaan. (1988).Kamus Besar Bahasa Indonesia. Jakarta: Balai Pustaka

Departemen Pendidikan Nasional. (2005). Kamus Besar Bahasa Indonesia. Jakarta: Balai Pustaka

Djamarah, Syaiful Bahri. (2000). Guru dan Anak Didik dalam Interksi Edukatif. Jakarta: PT. Rineka Cipta

Hisbullah. (2008). Dasar-Dasar Ilmu Pendidikan. Jakarta: PT Raja Grafindo Persada

lsmail, Imanuddin. (1998). Pengembangan Kemampuan Belajar Pada Anak. Jakarta: Bulan Bintang

Kembara, M.D. (2007). Panduan Lengkap Home Schooling. Bandung: Progresio

Lebar, A. Shaleh. (1998). Pengenalan Tingkat Sosiologi Sekolah dan Pendidikan. Selangor: Thinker Library SDN BND

Moleong, Lexy ]. (2004). Metodologi Penelitian Kualitatif. Bandung: PT. Remaja Rosdakarya

Mu'arif. (2008). Liberalisasi Pendidikan. Yogyakarta: Pinus Book Publisher

Muhadjir, Noeng. (1993). Ilmu Pendidikan dan Perubahan Sosial Suatu Teori Pendidikan. Yogyakarta: Rake Surasin

Mulyasa, E. (2001). Menjadi Guru Profesional Menciptakan pembelajaran Kreatif dan
Menyenangkan. Bandung : PT. Remaja Rosdakarya

Mustakim, Zaenal Mustakim. (2013). Strategi Dan Metode Pembelajaran. Pekalongan: STAIN Pekalongan Press

Naim, Ngainun dan Ahmad Syauqi. (2008). Pendidikan Multikultural : Konsep dan Aplikasi, Jogjakarta : Ar. Ruzz Media

Narbuko, Cholid dan Abu Achmadi. (2005). Metodologi Penelitian : Memberi Bekal Teoritispada Mahasiswa tentang Metodologi Penelitian serta diharapkan dapatMelaksanakan Penelitian dengan Langkah-Langkah yang Benar. Jakarta: PT. Bukti Aksara

Nurdin, M. (2005). Pendidikan yang Menyebalkan. Yogyakarta: Ar Ruzz

Sangadji, Etta Mamang dan Sopiah. (2010). Metodologi Penelitian Pendekatan Praktis dalam Penelitian. Yogyakarta: CV Andi Offcet

Sanjaya, Wina. (2012). Media Komunikasi Pembelajaran. Jakarta: Kencana Prenada Media Group

Sholehudin, M. Sugeng. (2009). Psikologi Perkembangan dalam Perspektif Pengantar. Pekalongan: STAIN Pekalongan Press

Singarimbun, Masri. Sofian Efendi. (2001). Metodologi Penelitian Survey. Jakarta: LP3ES

Sudijono, Anas. (2006). Pengantar Evaluasi Pendidikan. Jakarta: PT. Raja Grafindo Persada 
Sukardi. (2003). Metodologi Penelitian Pendidikan Kompetensi dan Praktiknya. Jakarta: BumiAksara

Tanpa

http://id.shvoong.com/social-

Nama, science/education/2175377-

pengertian-

liberalism/\#ixzzIVpdEP5Di.

Diakses tanggal 22 Januari 2020

Tanpa

Nama,

http://id.wikipedia.org/wiki/feoda

lisme. Diakses tanggal 22

Januari 2020

Tanpa

Nama,

http://sosbud.kompasiana.com/2 010/07/08/fenomena-feodalismedalam-karya-sastra-pramoedyabumi-manusia/. Diakses tanggal 22 Januari 2020

Tanpa

Nama, idbl.wikispaces.com/file/view/jjlo ol.pdf. Diakses tanggal 16 Februari 2020

Tim Penyusun PBM PAl di Sekolah. 1998. Yogyakarta: Pustaka Pelajar

Undang-undang Republik Indonesia Nomor 20 tahun 2003 tentang Sistem Pendidikan Nasional 
